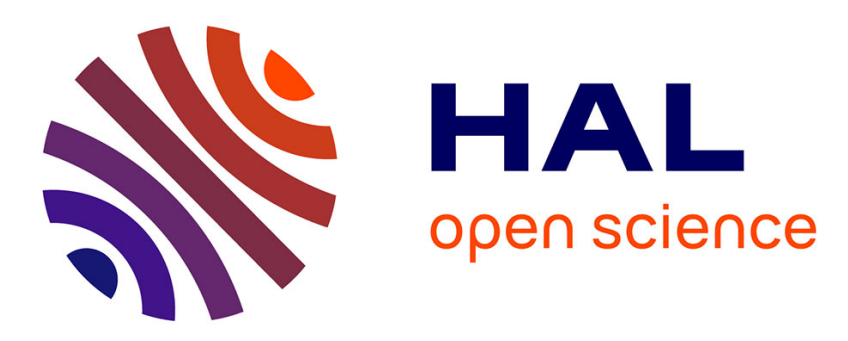

\title{
Synchronized autonomous sampling reveals coupled pulses of biomass and export of morphologically different diatoms in the Southern Ocean
}

Stéphane Blain, Mathieu Rembauville, Olivier Crispi, Ingrid Obernosterer

\section{- To cite this version:}

Stéphane Blain, Mathieu Rembauville, Olivier Crispi, Ingrid Obernosterer. Synchronized autonomous sampling reveals coupled pulses of biomass and export of morphologically different diatoms in the Southern Ocean. Limnology and Oceanography, 2020. hal-03002231

\section{HAL Id: hal-03002231 \\ https://hal.science/hal-03002231}

Submitted on 12 Nov 2020

HAL is a multi-disciplinary open access archive for the deposit and dissemination of scientific research documents, whether they are published or not. The documents may come from teaching and research institutions in France or abroad, or from public or private research centers.
L'archive ouverte pluridisciplinaire $\mathbf{H A L}$, est destinée au dépôt et à la diffusion de documents scientifiques de niveau recherche, publiés ou non, émanant des établissements d'enseignement et de recherche français ou étrangers, des laboratoires publics ou privés. 
1 Synchronized autonomous sampling reveals coupled pulses of biomass and export of

2 morphologically different diatoms in the Southern Ocean

3

4 Stéphane Blain*, Mathieu Rembauville, Olivier Crispi and Ingrid Obernosterer

5 Sorbonne Université, CNRS, Laboratoire d'océanographie microbienne, avenue Pierre Fabre,

666650 Banyuls sur mer, France

7

8 stephane.blain@obs-banyuls.fr

$9 \quad$ mathieu.rembauville@obs-banyuls.fr

10 olivier.crispi@obs-banyuls.fr

11 ingrid.obernosterer@obs-banyuls.fr

12

13

* Corresponding author

14

15 keywords : carbon stock, carbon export, diatoms, southern ocean, aggregates, seasonal time series, autonomous sampling

17 Running head : Pulses of diatom biomass and export 
ABSTRACT.

The Southern Ocean hosts a large diversity of diatoms that play a major role in carbon fluxes.

How the seasonal dynamics in the abundance of specific taxa in surface waters are linked to their contribution to carbon export remains, however, poorly understood. We present here synchronized observations from autonomous samplers deployed in the mixed layer (42 m) and at depth (300m) during an entire productive season (October 2016 to March 2017) in the iron fertilized region of the central plateau of Kerguelen. Microscopic observations of surface water collected every 11 days revealed 30 different diatom taxa, each contributing to $>1 \%$ of total carbon biomass throughout the season. The synchronised sampling revealed a common pattern for diatom taxa belonging to 12 different genera, consisting, for a given taxon, in short pulses of abundance in surface waters followed by export. We explain these coupled dynamics by the formation of aggregates that are produced when a critical diatom cell abundance is reached. This control of the maximum abundance of a given diatom drives the seasonal change in the slope of the size-class distribution of the diatom community. It further constrains the total carbon diatom biomass in a narrow range of values due to the inverse relationship between total diatom abundance and their community-weighted mean biomass. This coupling let us conclude that aggregate formation, and the export to depth, occurs throughout the season for diatoms with different morphologies. 
Introduction

During the past 250 million years diatoms have evolved a large diversity of forms and life styles (Armbrust 2009). They are successful unicellular phototrophic organisms that are present in almost all aquatic environments. They are characterized by an ornamented siliceous cell wall with diverse forms that serve as morphological criteria for species classification, an approach that is today complemented by DNA sequencing (Malviya et al. 2016). From a biogeochemical perspective, diatoms play a central role in the carbon cycle (Tréguer et al. 2018). In the past they have contributed to the lowering of atmospheric $\mathrm{CO}_{2}$ thanks to their efficiency to massively bury carbon in the sediment (Katz et al. 2005) and thereby formed large reservoirs of fossil fuels. In the contemporary ocean they contribute to $40 \%$ of global primary production (Nelson et al. 1995) and they sustain marine food webs. The success of diatoms is attributed to several features. On the one side, genomic adaptations (Armbrust et al. 2004; Allen et al. 2011) allow diatoms to thrive in various environments. They form blooms that can result in large sinking fluxes but require substantial nutrient supply, as provided in well-mixed water columns. This occurs preferentially in regions where turbulent water columns dominate (Margalef 1978). On the other side, the siliceous armour provides an efficient protection against predators, and possibly also against parasites and pathogens (Hamm and Smetacek 2007). The dense frustule enhances cell sinking (Smetacek 1985), necessitating elaborated strategies for maintaining the cells in the euphotic zone during the growth period (Raven and Waite 2004). The Southern Ocean hosts abundant and diverse communities of diatoms. Their ecology has been extensively described thanks to expeditions in different regions of the Antarctic circumpolar current (Queguiner et al. 1997; Tremblay et al. 2002; Leblanc et al. 2005) and to observations realised in naturally iron fertilized regions (Korb et al. 2008; Salter et al. 2012; 
Lasbleiz et al. 2016) or during artificial fertilization experiments (Gall et al. 2001; Assmy et al. 2013). Additional information was also gathered from investigations on the sinking en masse of the giant diatoms like Rhizosolenia spp. and Thalassiothrix spp. (Kemp et al. 2006) or of empty cells of Corethron criophylum (now named Corethron pennatum (Grunow) Ostenfeld) after entering the sexual stages (Crawford et al. 1997). One of the main motivation to link diatom ecology and biogeochemistry lies in the critical role they play in the carbon cycle (Tréguer et al. 2018). Their role as vectors of carbon export in the water column and storage at the seafloor has been demonstrated using sediment traps (Salter et al. 2012; RigualHernández et al. 2015; Rembauville et al. 2015a) and by the examination of sediments (Allen et al. 2005; Armand et al. 2008; Rigual-Hernández et al. 2016). Considering all these observations, conceptual frameworks linking diatom ecology and the carbon cycle in the Southern Ocean were derived.

Different biogeochemical roles were attributed to different diatom taxa (Quéguiner 2013; Assmy et al. 2013). For example, fast growing taxa characterized by en masse sinking behaviour (e.g. Chaetoceros, Thalasssiosira) were described as carbon sinkers or type 1, and highly silicified slow growing species as silica sinkers or type 2 . The dominance of one category over the other leads to a strong decoupling between the carbon and silicon cycles (Assmy et al. 2013). However, the coupling between the temporal dynamics of surface stocks and export at depth of diatoms at the taxon level is still poorly studied and understood, because it requires to collect samples evenly spaced in time during the entire growth season. This task is particularly challenging in the open ocean and even more in harsh environments like the Southern Ocean. In our study we have addressed this issue using synchronized autonomous samplers deployed for 4 months both within (42 $\mathrm{m}$ ) and below (300 m) the surface mixed layer. Our samples were collected in the long lasting 
89 Southern Ocean blooms that are sustained by natural iron fertilization above the Kerguelen

90 Plateau (Blain et al. 2007). Throughout the season, these blooms are dominated by a

91 succession of different diatom taxa (Lasbleiz et al. 2016; Rembauville et al. 2017). This

92 contrasts with spring to summer transitions in most oceanic regions where a succession of

93 diatoms and non diatoms are observed (Barber and Hiscock 2006). The Kerguelen plateau

94 waters therefore represent a unique environment for our investigations.

95 
MATERIALS AND METHODS

\section{Moorings.}

Two moorings were deployed during the SOCLIM cruise (doi/10.17600/16003300), one for the sediment traps on 13 October 2016, and one in subsurface waters on 18 October 2016. Both moorings were recovered on 7 April 2017. The sub surface mooring $\left(50^{\circ} 37^{\prime} 135 \mathrm{~S} /\right.$ $072^{\circ} 06^{\prime} 179 \mathrm{E}$, bottom depth $527 \mathrm{~m}$ ) was equipped with an aluminium framework located at $42 \mathrm{~m}$ below the surface that contained a remote access sampler (RAS Mac Lane) allowing the collection of $48 \times 500 \mathrm{~mL}$ samples. We collected 12 samples of unfiltered seawater every 11 th day, preserved either with glutaraldehyde or mercury chloride, and 18 filtered and unfiltered samples preserved with mercury chloride (Fig 1a). The sub surface framework was also equipped with a CTD sensor (SeabirdSBE 16) and a current meter (Aquadrop). Below the instrument package and down to $300 \mathrm{~m}$, the mooring line was equipped with additional temperature (SBE 56) and temperature/salinity sensors (SBE 37) to monitor changes in the mixed layer depth. The second mooring $\left(50^{\circ} 38^{\prime} 344 \mathrm{~S} / 71^{\circ} 59^{\prime} 854 \mathrm{E}\right.$, bottom depth $\left.527 \mathrm{~m}\right)$ was equipped with a Technicap PPS3 sediment trap $\left(0.125 \mathrm{~m}^{2}\right.$ collecting area, 4.75 aspect ratio) located at $300 \mathrm{~m}$ below the surface. The 12 cups $(250 \mathrm{ml})$ were filled with $5 \%$ formalin hypersaline solution buffered at $\mathrm{pH}=8$ with sodium tetraborate. The collection time for each cup was 11 days. After recovery of the RAS mooring the samples were immediately transferred from the bag into $500 \mathrm{~mL}$ clean polycarbonate bottles and stored in the dark at room temperature until processing in the laboratory. For the sediment traps, $1 \mathrm{ml}$ of the supernatant of the cups were replaced by fresh hypersaline formalin buffered $(\mathrm{pH}=8)$ solution before storage at room temperature. Upon recovery of the cups in the laboratory, the swimmers were removed and the samples split into eight aliquots using a Jencons peristaltic splitter (Rembauville et al. 2015b) 
121 Microscopic observations were conducted within four months after recovery of the

122 moorings. For the identification of diatoms, counting and size measurements, we used the 123 protocol described by (Salter et al. 2012) and modified by Rembauville et al. 2015a that 124 allows to separately consider full and empty cells. This issue is critical for our work which 125 aims to reconstruct the carbon flux and stock attributed to diatoms. For the preparations of 126 diatom counting (RAS or TRAP) the samples were processed as follows. For the RAS, 127 depending on the diatom abundance, $20 \mathrm{~mL}$, or $2 \mathrm{~mL}$ diluted with $18 \mathrm{~mL}$ of artificial seawater $(\mathrm{S}=34)$, were decanted in a Sedgewick Rafter counting chamber (Pyser SGE S52, $1 \mathrm{~mL}$ chamber volume). For the trap samples, $2 \mathrm{~mL}$ of one-eight aliquot was diluted with 18 $\mathrm{mL}$ of artificial seawater and decanted in a Sedgewick Rafter counting chamber. Diatoms were enumerated and identified under an inverted microscope with phase contrast (Olympus IX170) at magnification 400X. The morphometric measurements were done using high resolution images (Olympus DP71 camera) and Fiji image processing software. The biovolume was calculated from morphometric measurements (Hillebrand et al. 1999). The carbon content was derived from biovolumes using allometric relationships reported in the literature (Menden-Deuer and Lessard 2000; Cornet-Barthau et al. 2007) and taking into

137 account specific relationships for spores (Rembauville et al. 2015a). The size-abundance distributions of the diatom community collected at a given time point was based on an octave ( $\log 2)$ scale of cell volume.

\section{Diatom carbon stocks and export fluxes.}

141 The carbon stock accounted for by diatoms was calculated by summing up the contributions 142 of the different taxa. The integrated diatom carbon stock was calculated by multiplying the 
total carbon contained in full diatoms ( $\mathrm{POC}_{\text {diat }}$ ) by the mean mixed layer depth at the sampling time.

The export flux of diatoms was calculated using the equation:

$$
\text { Cell flux }=N_{\text {diat }} \times d \times 8 \times V_{\text {aliquot }} \times \frac{1}{0.125} \times \frac{1}{11} \times k
$$

Where $\mathrm{N}_{\text {diat }}\left(\right.$ cell $\mathrm{m}^{-2} \mathrm{~d}^{-1}$ ) is the number of cells counted in one chamber, $\mathrm{d}$ is the dilution factor, $V_{\text {aliquot }}$ is the volume of the aliquot, and $\mathrm{k}$ is the fraction of the chamber counted.

The diatom flux was then converted to POC flux for each taxon using allometric equations.

\section{Biogeochemical analysis.}

Dissolved major nutrients $\left(\mathrm{NO}_{3}{ }^{-}\right.$and $\left.\mathrm{Si}(\mathrm{OH})_{4}\right)$ in the RAS were measured in the $0.8 \mu \mathrm{m}$ filtered (polycarbonate filters ) samples preserved with mercuric chloride using standard protocols that have been previously applied to samples of this site (Blain et al. 2015).

\section{Community weighted mean (CWM) .}

CWM is defined using the equation

$$
C W M=\sum_{i=1}^{N} p_{i} \times C_{\text {diat }, i}
$$

where for the taxa $\mathrm{i}, \mathrm{p}_{\mathrm{i}}$ is its relative abundance and $\mathrm{C}_{\text {diat, } \mathrm{i}}$ is its carbon content.

To estimate the effect of the variability of the diatom composition on the CWM we simulated virtual diatom communities. We first randomly selected 14 taxa among the 30 taxa contributing to at least $1 \%$ of the biomass and then we allocated to these selected diatom taxa a random abundance ranging between 0 and their respective maximum abundance observed during the season. Finally $\mathrm{N}_{t}$ and CWM were calculated. The simulation was repeated 1000 times.

\section{Calculation of the critical cell concentrations.}

The critical cell concentration was calculated according to the equation of (Jackson 1990) . 
$C_{C r}\left(\right.$ cell $\left.m^{-3}\right)=\frac{0.096 \times \mu}{\alpha \times \gamma \times E S R^{3}}$ where ESR is the Equivalent Spherical Radius $(\mathrm{m}), \mu$ is the net

167 growth rate $\left(s^{-1}\right), \alpha$ is the stickiness and $\gamma$ is the shear rate $\left(s^{-1}\right)$ estimated according to the 168 formulation (MacKenzie and Leggett 1993).

$169 \quad \gamma=\sqrt{\frac{\varepsilon}{\vartheta}}$ where $\varepsilon=\left(\frac{\tau}{\rho_{w}}\right)^{3 / 2} \times \frac{1}{k Z}$

$170 \tau$ is the mean wind stress of $0.22 \mathrm{Nm}^{-2}$ for the period of interest obtained from the Japanese

171 55-yr reanalysis (JRA-55; available online at http://jra.kishou.go.jp). $v$ is seawater kinematic

172 viscosity $\left(10^{-6} \mathrm{~m}^{2} \mathrm{~s}^{-1}\right), \rho_{\mathrm{w}}$ is the seawater density in the mixed layer $\left(1027 \mathrm{~kg} \mathrm{~m}^{-3}\right) . \mathrm{k}$ is the von

173 Kármán constant (0.41) and Z is the mixed layer depth (70 m).

174 Simulations represented in SI Fig. 3 were obtained using the equations above with different

175 values of $\alpha(0.1,0.25,0.5$ and 1$)$ and $\mu\left(0.05\right.$ and $\left.0.13 d^{-1}\right)$. 
RESULTS

\section{Environmental context and temporal phytoplankton bloom dynamics}

The region of interest for our study is located south-east of Kerguelen island on the central part of the Kerguelen Plateau (Figure 1a). The sampling site is located in a zone that has been identified during previous studies in Jan-Feb 2005 (Blain et al. 2007) and Oct-Nov 2011 (Blain et al. 2015) as the core of the Kerguelen bloom. The ocean colour satellite images for the season 2016-2017 confirm that the large bloom, typical of this region, was also present during the time period considered here. The temporal variations of surface chlorophyll in the vicinity of the sampling site show the succession of two blooms peaking in November and January (Figure 1B). This seasonal pattern is consistent with the dual blooms as revealed from the climatology for this site (Figure 1B). Ocean colour images combined with backtrajectories derived from current speeds and directions at $42 \mathrm{~m}$ (SI Figure 1) show that the horizontal advection of surface water parcels that reached the sampling site during a time step of 11 days did not result in large variability of chlorophyll. The influence of spatial variability was therefore limited and we will interpret changes observed at the sampling site as mainly resulting from temporal variability.

The seasonal changes of the mixed layer depth (MLD) show that all the samples collected by the RAS were located in the mixed layer (Figure 2A). The variation of diatom carbon biomass integrated over the mixed layer, which accounted for the surface biomass (Pellichero et al. 2020), presented similar temporal variations to chlorophyll concentrations (Figure 2C). The build-up of diatom biomass affected the concentrations of major nutrients in surface waters (Figure 2D). The concentrations of nitrate and silicic acid were high at the beginning of the season and decreased during the first bloom. This decrease was much larger for silicic acid 
than for nitrate. Silicic acid concentrations increased slightly after the first bloom before being further depleted after the second bloom.

\section{Temporal dynamics of surface diatom communities}

\section{Main taxa contributing to carbon biomass}

Throughout the season, the Kerguelen blooms were dominated by diatoms (Lasbleiz et al. 2016; Rembauville et al. 2017), in contrast to blooms in temperate regions where diatoms are replaced by other phytoplankton during part of the productive season (Barber and Hiscock 2006). For the RAS time series, diatoms accounted for $89 \pm 9 \%$ of carbon phytoplankton biomass observed by microscopy supporting the idea of diatom dominance. Because we wanted to explore the relationship between biogeochemistry (carbon biomass and export) and composition of the diatom community, we describe the latter using microscopic observations rather than DNA sequencing. In this context, the advantages of microscopic observations are that they allow the taxonomic identification, the determination of absolute counts of full cells (i.e; containing carbon) and quantitative estimates of the carbon content $\left(C_{\text {diat }}\right)$ derived from size measurements (Hillebrand et al. 1999; Menden-Deuer and Lessard 2000; Cornet-Barthau et al. 2007). In the following, we consider only diatoms at the genus or species level (hereafter referred to as taxa) that contribute to $>1 \%$ of the total diatom $\mathrm{C}$ biomass $\left(\mathrm{POC}_{\text {diat }}\right)$. In the mixed layer, we identified a total of 30 different taxa during the entire season (Fig. 2 b). The number of taxa was relatively constant throughout the season $(\min =11, \max =15$, median $=14$ ), whereas the composition of the community varied dramatically (Fig. 2B). The first peak of Chlorophyll and POC $_{\text {diat }}$ (Fig. 2c) was dominated by taxa with low $C_{\text {diat, }}$ typically Chaetoceros (Hyalochaete), Thalassiosira antarctica, including their resting spores, and other small centric diatoms. The 
second maximum of Chlorophyll a and $\mathrm{POC}_{\text {diat }}$ was dominated by taxa characterized by high

$C_{\text {diat }}$ (Eucampia antarctica, Corethron inerme, Ondotella weissflogii, Thalasssiothrix antarctica) with the exception of the pennate Pseudo-nitzchia, a genus commonly identified in artificially iron fertilized blooms (Marchetti et al. 2012). The iconic pennate species of the Southern Ocean Fragilariopsis kerguelensis had substantial contributions to $\mathrm{POC}_{\text {diat }}$ in our first sample (25 October). Its contribution continuously decreased as the first bloom developed, became negligible during the second bloom and started to recover in late summer.

\section{Seasonal changes of abundance, size and carbon content.}

The abundance of the main diatom taxa ( 30 in total) contributing to the total carbon biomass $\mathrm{POC}_{\text {diat }}$ varied by 3 orders of magnitude and their individual biovolumes varied by more than 3 orders of magnitude (from $112 \mu \mathrm{m}^{3}$ up to $152600 \mu \mathrm{m}^{3}$ ). To examine how these variations affect the total carbon biomass $\mathrm{POC}_{\text {diat, }}$ we characterized the diatom communities observed at 12 time points during the season in two different manners.

In the first approach, we used the diatom community size spectrum. The slope of the size spectra revealed marked changes throughout the season (Table 1 and SI Fig. 2).

At the beginning of the season, the slope was within the range $[-0.8,-0.7]$. By mid-December which coincided with the end of the declining phase of the first bloom, the slope increased rapidly up to values in the range $[-0.2,-0.3]$, and these values were maintained until the last week of February. These latter slopes were less significant due to one or two outliers located in the middle of the size-class range that could indicate a bi-modal distribution rather than a linear one. At the end of February, the slope increased to a value of -0.51 . 
If we consider that the biovolume scales with the diatom abundance, as shown by the size

248

249

250

251

252

253

254

255

256

257

258

259

260

261

262

263

264

265

266

267

268

269

spectrum, and if the individual carbon content of diatoms scales with the biovolume as

supported by previous studies (Menden-Deuer and Lessard 2000; Cornet-Barthau et al.

2007), it is in principle possible to sum up the contributions of the different size classes to

obtain the total carbon biomass $\mathrm{POC}_{\text {diat }}$ of the community. However, this approach could be biased if the contribution of diatom spores to a size class is non-negligible. Indeed, the volumetric carbon content of a spore is higher than that of a vegetative cell (Rembauville et al. 2015a).

For this reason we also characterized the diatom communities using a second approach and estimated the community weighted mean (CWM) (Fig. 3A). Obviously, the CWM and the total carbon biomass $\mathrm{POC}_{\text {diat }}$ are linked using the equation $\mathrm{POC}_{\text {diat }}=\mathrm{N}_{\mathrm{t}} \times \mathrm{CWM}$ where $\mathrm{N}_{t}$ is the total abundance of diatoms of the community. CWM and $\mathrm{N}_{t}$ show clear opposite seasonal trends, increasing and decreasing, respectively, throughout the season (Fig. 3A, B). These changes provided insight to the seasonal variations of the total diatom carbon biomass.

\section{Coupling between diatom taxa in surface waters and their export}

The carbon fluxes attributed to diatoms in each cup of the sediment trap are presented in Fig. 4A. The first export event was mainly collected by cups \#3, \#4 and \#5. The cumulated flux in these 3 cups was $3.9 \mathrm{mmol} \mathrm{C} \mathrm{m}^{-2} \mathrm{~d}^{-1}$ and it represented $60 \%$ of the seasonal diatom carbon flux. The second event was recorded in cups \# 9 and \#10 and the corresponding

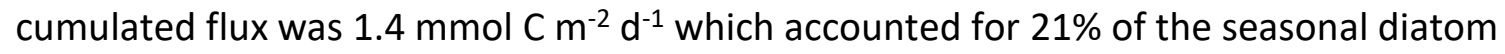
carbon flux. The seasonal pattern of diatom carbon export was remarkably similar to those observed in 2011-2012 at the same site (Rembauville et al. 2015b). 
The relative contributions of the different taxa to diatom carbon export are shown in Fig. 4B.

271

The first event was entirely dominated by the export of Chaetoceros and Thalassiosira resting spores while more diverse taxa were contributing to the second event. For the latter, when cups \#9 and \#10 are cumulated, the relative contributions of the different taxa were: Chaetoceros resting spores (43\%), Pseudo-nitzschia heimii (2\%), Pseudo-nitzschia lineola (3\%), Navicula directa (0.7\%), Eucampia antarctica (20.4\%), Corethron inerme (4.2\%), Odontella weisflogii spores (15.3\%), Proboscia inermis (1.3\%), Thalassiothrix antarctica (3,6\%), Membraneis challenger (5\%), Rhizosolenia styliformis (1.5\%), Asteromphalus hookeri(1.7\%).

The synchronized sampling of diatom communities in the mixed layer and in the sediment traps (Fig. 2A) allowed a detailed investigation of the coupling between the dynamics of the abundance of individual diatom taxa in the mixed layer and of their export at $300 \mathrm{~m}$. To compare both dynamics we calculated, for a given genus, its relative contribution at each time point to its total seasonal abundance and to its total seasonal export flux (Fig. 5). It is evident that the maximum seasonal abundance of the different diatom genera in the mixed layer occurred during a short time period, closely followed by a carbon export event of the same genus. We observed that more than $44.2 \%$ (for Thalassionema) and up to $100 \%$ (for Proboscia) of the seasonal export attributable to a given genus took place during a relatively short time period, representing $17 \%$ of the entire sampling period ( 132 days) (Table 2). To confirm the link between the dynamics of diatom surface abundance and export we estimated for each genus the correlation between the two time series with different time lags (SI Fig. 3). The correlation is significant for 10 of the genera, the exceptions being Fragilariopsis and Odontella. The time lag leading to the best correlation between both time series was 0 day for Membraneis, Thalassiosira, 11 days for Proboscia, 

Thalassiothrix.

\section{DISCUSSION}

Our study was designed to address the coupling between the seasonal dynamics of diverse diatoms in the surface layer and their export at depth. Our major aim was to refine previous conceptual views both on a temporal scale and on the taxon level, and thereby to make an important step forward. Thanks to the seasonal coverage with good temporal resolution, and to the synchronized observations between the surface layer and at depth we are able to reveal a common pattern for diatom species belonging to 10 different genera that are short pulses of surface abundance followed by export.

Short-term artificial iron fertilization experiments in the Southern Ocean and more specifically the 35 days long EIFEX cruise (Smetacek et al. 2012) revealed the critical role of the pulsed nature of POC export due to boom-and-burst diatoms (Assmy et al. 2013) exemplified by Chaetoceros dichaeta. On a seasonal scale, the pulsed export of different diatom taxa was inferred from sediment trap deployments in the Australian sector of the Southern Ocean. The relative abundance of Pseudo-nitzschia and of the small Fragilariopsis spp. in sediment traps was closely related to POC pulses in the Polar Front and in the Sub Antarctic zones (Rigual-Hernández et al. 2016). Similar observations were made for Fragilariopsis kerguelensis and Thalassiothrix antarctica in the Antarctic zone (RigualHernández et al. 2015). However, seasonal changes of the surface diatom communities were not described in these previous studies, limiting further investigation of the origin of these diatom pulses for carbon export. In addition, empty and full diatom cells were not distinguished by the methodology applied (Romero et al. 2000). 
taxa, but it also allows us to go a step further and to address the question: what causes such a common pattern? To answer this question, we start with the examination of the seasonal changes of diatom abundance and size in the mixed layer. The maximum abundance reached during the season by diatoms belonging to 12 different genera was strongly related to size, characterized by the spherical equivalent radius (Fig 6 and SI Fig. 4).

Our simulation (Fig. 3D) shows that this unique constraint, that is size, produces an envelope of communities characterized by $\mathrm{CWM}$ and $\mathrm{N}_{\mathrm{t}}$ consistent with the communities observed in situ.

The slopes of the size-class spectrum determined in our study at the beginning of the season were close to those reported for coastal eutrophic and upwelling ecosystems (around -0.8; Cermeño and Figueiras 2008), while slopes up to -1.3 are reported for subtropical regions (Cermeño and Figueiras 2008). A 10 year time series at a shelf station in a temperate region revealed little variation $(-0.96)$, with only episodically low slopes $(-0.6)$ during the relaxation of upwelling (Huete-Ortega et al. 2010). In comparison, the slopes obtained in the present study during the second part of the season $(-0.29$ to -0.25$)$ are low. Both, the changes of the slope of the size-class spectrum (Table 1) and of the CWM are explained by the replacement of small and abundant diatoms during the first part of the season by large and less abundant diatoms during summer. The paradigm that small phytoplankton dominate when resources are limited, as is typically the case in oligotrophic gyres, and that large cells thrive when sufficient amounts of resources are available, typical for coastal environments or upwelling regions, has been invoked to explain spatial differences in the slopes of the phytoplankton community size spectrum and can be explained by the size scaling of nutrient requirements and growth 
(Irwin et al. 2006). Our observations that large cells dominate in summer when essential

343

344

nutrients like silicic acid (Fig. 2D) and iron (Blain et al. 2008) are at their lowest values seems at odds with this explanation. Therefore, another mechanism should control the size distribution of the diatom communities in this region. We propose the formation of diatom aggregates as an explanation. The first observations of diatom aggregates have been reported by (Billett et al. 1983; Smetacek 1985). Theoretical approaches have shown that the formation of aggregates occurs when a critical cell abundance is reached for given environmental and cell properties (Jackson 1990) and such predictions have been confirmed in situ (Boyd et al. 2002). The critical abundances calculated by Jackson's model were also consistent with POC and biovolumes determined at the Bermuda Atlantic time series and off southern California (Jackson and Kiørboe 2008). In the Kerguelen bloom the formation of aggregates has been suggested to occur during the spring bloom based on in situ observations of changes in the size spectrum and modelling (Jouandet et al. 2014). The critical abundance depends on both, the properties of diatoms (ESR, stickiness, and net growth rate) and the properties of the environment (shear rate). When applying our data to an aggregation model (Jackson 1990), it showed that the observed maximum abundances for individual taxa (Fig. 6), or for size classes (SI Fig. 4) was determined by the net-growth rate and the stickiness of individual diatom taxa.

that can vary largely depending on the taxa (Kiørboe et al. 1990), the agreement between the model and the data is better with $\alpha=1$ for small cells $\left(\mu=0.13 \mathrm{~d}^{-1}\right)$. The maximum abundances are even below the critical abundances predicted by the model with this value of $\alpha$. It is conceivable that the ESR of small cells is underestimated in the context of the formation of aggregates 
because it does not take into account the presence of spines, which likely increase the ESR. For

the larger cell (or size classes), that were growing around $\mu=0.05 \mathrm{~d}^{-1}$, the better fitting is obtained for values of $\alpha$ in the range $0.5-0.25$ (Fig. 6 and SI Fig. 4). This suggests that the stickiness of these larger cells would be lower. These results obtained at the diatom taxon level extend the previous conclusion of Jackson and Kiørboe 2008 obtained for bulk POC that the formation of diatom aggregates is a major factor of control for the maximum diatom abundance and consequently for their export.

When aggregates formed in the mixed layer are exported below the mixed layer depth, pulsed export events are expected. This was obviously the case considering the pulsed export dynamics observed in the present study (Fig. 5). We note that a similar seasonal pattern of carbon diatom export was observed in 2011-2012 at the same site (Rembauville et al. 2015a) suggesting that there is little interannual variability in the shape and magnitude of the carbon fluxes transported by diatoms. However, in the present study the total seasonal flux of POC was roughly 10 times higher than in 2011-2012 suggesting a large interannual variability in the carbon export due to faecal pellets. This observation is puzzling and advocates for seasonal monitoring of the composition of zooplankton community composition. Such observations were technically not feasible during the present study, but the rapid ongoing technological developments of underwater video profilers integrated to profiling floats (Claustre et al. 2020) or moorings provide promising perspectives for the near future.

Our sediment trap samples were collected using cups filled with hypersaline solution, and transported back to the laboratory for processing, including splitting. This protocol is not as well adapted to preserve aggregates as the collection and direct observation with gel traps (Ebersbach and Trull 2008). Considering the different estimates of 
time lags we can also estimate the sinking velocity of aggregates. These are in the range 25 to $250 \mathrm{~m} \mathrm{~d}^{-1}$ and thus in good agreement with values determined in rolling tanks for aggregates formed with different Southern Ocean diatoms ([13- $\left.260 \mathrm{~m} \mathrm{~d}^{-1}\right]$; LaurenceauCornec et al. 2015). Collectively, our observations let us conclude that the formation of diatom aggregates occurs throughout the season, and is driven by a threshold in the abundance of a given diatom taxon. This leads to pulsed temporal dynamics in the abundance of diatoms with diverse morphology and their export to depth. The control of the maximum abundance of a given diatom by the formation of aggregates drives the seasonal change in the slope of the size-class distribution of the diatom community. It also constrains the total carbon diatom biomass in a narrow range of values due to the inverse relationship between $N_{t}$ and

401 CWM.

402 
References

Allen, A. E., C. L. Dupont, M. Oborník, and others. 2011. Evolution and metabolic significance of the urea cycle in photosynthetic diatoms. Nature 473: 203.

Allen, C. S., J. Pike, C. J. Pudsey, and A. Leventer. 2005. Submillennial variations in ocean conditions during deglaciation based on diatom assemblages from the southwest Atlantic: diatom record from the falkland through. Paleoceanography 20: n/a-n/a. doi:10.1029/2004PA001055

Armand, L. K., X. Crosta, B. Quéguiner, J. Mosseri, and N. Garcia. 2008. Diatoms preserved in surface sediments of the northeastern Kerguelen Plateau. Deep Sea Research Part II: Topical Studies in Oceanography 55: 677.

Armbrust, A. V., J. A. Berges, C. Bowler, and others. 2004. The genome of th diatom Thalassiosira pseudonana: ecoly, evolution and metabolism. Science 306: 79-86.

Armbrust, E. V. 2009. The life of diatoms in the world's oceans. Nature 459: 185-192. doi:10.1038/nature08057

Assmy, P., V. Smetacek, M. Montresor, and others. 2013. Thick-shelled, grazer-protected diatoms decouple ocean carbon and silicon cycles in the iron-limited Antarctic Circumpolar Current. Proceedings of the National Academy of Sciences 110: 20633-20638. doi:10.1073/pnas.1309345110

Barber, R. T., and M. R. Hiscock. 2006. A rising tide lifts all phytoplankton: Growth response of other phytoplankton taxa in diatom-dominated blooms: A RISING TIDE RAISES ALL PHYTOPLANKTON. Global Biogeochem. Cycles 20: n/a-n/a. doi:10.1029/2006GB002726

Billett, D. S. M., R. S. Lampitt, A. L. Rice, and R. F. C. Mantoura. 1983. Seasonal sedimentation of phytoplankton to the deep-sea benthos. Nature 302: 520-522. doi:10.1038/302520a0

Blain, S., J. Capparos, A. Guéneuguès, I. Obernosterer, and L. Oriol. 2015. Distributions and stoichiometry of dissolved nitrogen and phosphorus in the iron-fertilized region near Kerguelen (Southern Ocean). Biogeosciences 12: 623-635. doi:10.5194/bg-12-623-2015 
Blain, S., B. Quéguiner, L. Armand, and others. 2007. Effect of natural iron fertilisation on carbon sequestration in the Southern Ocean. Nature 446: 1070-1075. doi:doi:10.1038/nature05700

Blain, S., G. Sarthou, and P. Laan. 2008. Distribution of dissolved iron during the natural ironfertilization experiment KEOPS (Kerguelen Plateau, Southern Ocean). Deep Sea Research Part II: Topical Studies in Oceanography 55: 594.

Boyd, P. W., G. A. Jackson, and A. M. WAite. 2002. Are mesoscale perturbation experiments in polar waters prone to physical artefacts? Evidence from algal aggregation modelling studies. Geophysical Research Letters 20: doi: 10.1029/2001GL014210.

Cermeño, P., and F. Figueiras. 2008. Species richness and cell-size distribution: size structure of phytoplankton communities. Mar. Ecol. Prog. Ser. 357: 79-85. doi:10.3354/meps07293

Claustre, H., K. S. Johnson, and Y. Takeshita. 2020. Observing the Global Ocean with BiogeochemicalArgo. Annu. Rev. Mar. Sci. 12: 23-48. doi:10.1146/annurev-marine-010419-010956

Cornet-Barthau, V., L. Armand, and B. Quéguiner. 2007. Biovolume and biomass estimates of key diatoms in the Southern Ocean. Aquatic Microbial Ecology 48: 295-308.

Crawford, R. M., F. Hinz, and T. Rynearson. 1997. Spatial and temporal distribution of assemblages of the diatom Corethron criophilum in the Polar Frontal region of the South Atlantic. Deep Sea Research Part II: Topical Studies in Oceanography 44: 479.

Ebersbach, F., and T. Trull. 2008. Sinking particle properties from polyacrylamide gels during KEOPS: zooplankton control of carbon export in an area of persistent natural iron inputs in the Southern Ocean. Limnology and Oceanography 53: 212-224.

Gall, M. P., R. Strzepek, M. Maldonado, and P. W. Boyd. 2001. Phytoplankton processes. Part 2: Rates of primary production and factors controlling algal growth during the Southern Ocean Iron RElease Experiment (SOIREE). Deep Sea Research Part II: Topical Studies in Oceanography 48: 2571.

Hamm, C., and V. Smetacek. 2007. Armor: Why, When, and How, p. 311-332. In Evolution of Primary Producers in the Sea. Elsevier. 
Hillebrand, H., C.-D. Dürselen, D. Kirschtel, U. Pollingher, and T. Zohary. 1999. Biovolume calculation for pelagic and benthic microalgae. Journal of Phycology 35: 403-424. doi:10.1046/j.15298817.1999.3520403.x

Huete-Ortega, M., E. Maranon, M. Varela, and A. Bode. 2010. General patterns in the size scaling of phytoplankton abundance in coastal waters during a 10-year time series. Journal of Plankton Research 32: 1-14. doi:10.1093/plankt/fbp104

Irwin, A. J., Z. V. Finkel, O. M. E. Schofield, and P. G. Falkowski. 2006. Scaling-up from nutrient physiology to the size-structure of phytoplankton communities. Journal of Plankton Research 28: 459-471. doi:10.1093/plankt/fbi148

Jackson, G. A. 1990. A model of the formation of marine algal flocs by physical coagulation processes. Deep Sea Research Part A. Oceanographic Research Papers 37: 1197-1211. doi:10.1016/0198-0149(90)90038-W

Jackson, G. A., and T. Kiørboe. 2008. Maximum phytoplankton concentrations in the sea. Limnol. Oceanogr. 53: 395-399. doi:10.4319/lo.2008.53.1.0395

Jouandet, M.-P., G. A. Jackson, F. Carlotti, M. Picheral, L. Stemmann, and S. Blain. 2014. Rapid formation of large aggregates during the spring bloom of Kerguelen Island: observations and model comparisons. Biogeosciences 11: 4393-4406. doi:10.5194/bg-11-4393-2014

Katz, M. E., J. D. Wright, K. G. Miller, B. S. Cramer, K. Fennel, and P. G. Falkowski. 2005. Biological overprint of the geological carbon cycle. Marine Geology 217: 323-338. doi:10.1016/j.margeo.2004.08.005

Kemp, A. E. S., R. B. Pearce, I. Grigorov, J. Rance, C. B. Lange, P. Quilty, and I. Salter. 2006. Production of giant marine diatoms and their export at oceanic frontal zones: Implications for Si and C flux from stratified oceans. Global Biogeochemical Cycles 20. doi:10.1029/2006GB002698

Kiørboe, T., K. P. Andersen, and H. G. Dam. 1990. Coagulation efficiency and aggregate formation in marine phytoplankton. Mar. Biol. 107: 235-245. doi:10.1007/BF01319822 
Korb, R., M. Whitehouse, A. Atkinson, and S. Thorpe. 2008. Magnitude and maintenance of the phytoplankton bloom at South Georgia: a naturally iron-replete environment. Mar. Ecol. Prog. Ser. 368: 75-91. doi:10.3354/meps07525

Lasbleiz, M., K. Leblanc, L. K. Armand, U. Christaki, C. Georges, I. Obernosterer, and B. Quéguiner. 2016. Composition of diatom communities and their contribution to plankton biomass in the naturally iron-fertilized region of Kerguelen in the Southern Ocean G. King [ed.]. FEMS Microbiology Ecology 92: fiw171. doi:10.1093/femsec/fiw171

Laurenceau-Cornec, E., T. Trull, D. Davies, C. De La Rocha, and S. Blain. 2015. Phytoplankton morphology controls on marine snow sinking velocity. Marine Ecology Progress Series 520: 35-56. doi:10.3354/meps 11116

Leblanc, K., C. E. Hare, P. W. Boyd, and others. 2005. Fe and Zn effects on the Si cycle and diatom community structure in two contrasting high and low-silicate HNLC areas. Deep Sea Research Part I: Oceanographic Research Papers 52: 1842-1864. doi:10.1016/j.dsr.2005.06.005

MacKenzie, B. R., and W. C. Leggett. 1993. Wind-based models for estimating the dissipation rates of turbulent energy in aquatic environments: empirical comparisons. Marine Ecology Progress Series 94: 207-216.

Malviya, S., E. Scalco, S. Audic, and others. 2016. Insights into global diatom distribution and diversity in the world's ocean. Proceedings of the National Academy of Sciences 113: E1516-E1525. doi:10.1073/pnas.1509523113

Marchetti, A., D. M. Schruth, C. A. Durkin, and others. 2012. Comparative metatranscriptomics identifies molecular bases for the physiological responses of phytoplankton to varying iron availability. Proceedings of the National Academy of Sciences 109: E317-E325. doi:10.1073/pnas.1118408109

Margalef, R. 1978. Life-form of phytoplankton as survival alternatives in an unstable environment. Oceanologica Acta 1: 493-509. 
Menden-Deuer, S., and E. J. Lessard. 2000. Carbon to volume relationships for dinoflagellates, diatoms, and other protist plankton. Limnol. Oceanogr. 45: 569-579. doi:10.4319/lo.2000.45.3.0569

Nelson, D. M., P. Tréguer, M. A. Brzezinski, A. Leynaert, and B. Quéguiner. 1995. Production and dissolution of biogenic silica in the ocean: Revised global estimates, comparison with regional data and relationship to biogenic sedimentation. Global Biogeochem. Cycles 9: 359-372. doi:10.1029/95GB01070

Pellichero, V., J. Boutin, H. Claustre, L. Merlivat, J. Sallée, and S. Blain. 2020. Relaxation of Wind Stress Drives the Abrupt Onset of Biological Carbon Uptake in the Kerguelen Bloom: A Multisensor Approach. Geophys. Res. Lett. 47. doi:10.1029/2019GL085992

Quéguiner, B. 2013. Iron fertilization and the structure of planktonic communities in high nutrient regions of the Southern Ocean. Deep Sea Research Part II: Topical Studies in Oceanography 90: 43-54. doi:10.1016/j.dsr2.2012.07.024

Queguiner, B., P. Treguer, I. Peeken, and R. Scharek. 1997. Biogeochemical dynamics and the silicon cycle in the Atlantic sector of the Southern Ocean during austral spring 1992. Deep Sea Research Part II: Topical Studies in Oceanography 44: 69.

Raven, J. A., and A. M. Waite. 2004. The evolution of silicification in diatoms: inescapable sinking and sinking as escape? New Phytol 162: 45-61. doi:10.1111/j.1469-8137.2004.01022.x

Rembauville, M., S. Blain, L. Armand, B. Quéguiner, and I. Salter. 2015a. Export fluxes in a naturally iron-fertilized area of the Southern Ocean - Part 2: Importance of diatom resting spores and faecal pellets for export. Biogeosciences 12: 3171-3195. doi:10.5194/bg-12-3171-2015

Rembauville, M., N. Briggs, M. Ardyna, and others. 2017. Plankton Assemblage Estimated with BGCArgo Floats in the Southern Ocean: Implications for Seasonal Successions and Particle Export: Journal of Geophysical Research: Oceans 122: 8278-8292. doi:10.1002/2017JC013067

Rembauville, M., I. Salter, N. Leblond, A. Gueneugues, and S. Blain. 2015b. Export fluxes in a naturally iron-fertilized area of the Southern Ocean - Part 1: Seasonal dynamics of particulate organic 

carbon export from a moored sediment trap. Biogeosciences 12: 3153-3170. doi:10.5194/bg-12-3153-2015

Rigual-Hernández, A. S., T. W. Trull, S. G. Bray, and L. K. Armand. 2016. The fate of diatom valves in the Subantarctic and Polar Frontal Zones of the Southern Ocean: Sediment trap versus surface sediment assemblages. Palaeogeography, Palaeoclimatology, Palaeoecology 457: 129-143. doi:10.1016/j.palaeo.2016.06.004

Rigual-Hernández, A. S., T. W. Trull, S. G. Bray, I. Closset, and L. K. Armand. 2015. Seasonal dynamics in diatom and particulate export fluxes to the deep sea in the Australian sector of the southern Antarctic Zone. Journal of Marine Systems 142: 62-74. doi:10.1016/j.jmarsys.2014.10.002

Romero, O. E., G. Fischer, C. B. Lange, and G. Wefer. 2000. Siliceous phytoplankton of the western equatorial Atlantic: sediment traps and surface sediments. Deep Sea Research Part II: Topical Studies in Oceanography 47: 1939-1959. doi:10.1016/S0967-0645(00)00012-6

Salter, I., A. E. S. Kemp, C. M. Moore, R. S. Lampitt, G. A. Wolff, and J. Holtvoeth. 2012. Diatom resting spore ecology drives enhanced carbon export from a naturally iron-fertilized bloom in the Southern Ocean. Global Biogeochemical Cycles 26. doi:10.1029/2010GB003977

Smetacek, V., C. Klaas, V. H. Strass, and others. 2012. Deep carbon export from a Southern Ocean iron-fertilized diatom bloom. Nature 487: 313-319. doi:10.1038/nature11229

Smetacek, V. S. 1985. Role of sinking in diatom life-history cycles: ecological, evolutionary and geological significance. Marine Biology 84: 239-251. doi:10.1007/BF00392493

Tréguer, P., C. Bowler, B. Moriceau, and others. 2018. Influence of diatom diversity on the ocean biological carbon pump. Nature Geoscience 11: 27-37. doi:10.1038/s41561-017-0028-x

Tremblay, J. E., M. I. Lucas, G. Kattner, R. Pollard, V. H. Strass, U. Bathmann, and A. Bracher. 2002. Significance of the Polar Frontal Zone for large-sized diatoms and new production during summer in the Atlantic sector of the Southern Ocean. Deep Sea Research Part II: Topical Studies in Oceanography 49: 3793. 
Table 1 : Seasonal changes of diatom communities size class spectrum parameters where

559 biovolume were in $\mu \mathrm{m}^{3}$ and abundance in cell $\mathrm{L}^{-1}$

\begin{tabular}{|l|l|l|l|l|l|}
\hline date & sample & slope & intercept & R_squared & $p$ \\
\hline $10 / 25 / 2016$ & 1 & -0.81 & 7.001 & 0.563 & 0.012 \\
\hline $11 / 06 / 2016$ & 2 & -0.82 & 7.683 & 0.529 & 0.017 \\
\hline $11 / 17 / 2016$ & 3 & -0.73 & 7.225 & 0.732 & 0.003 \\
\hline $11 / 28 / 2016$ & 4 & -0.71 & 7.082 & 0.745 & 0.002 \\
\hline $12 / 09 / 2016$ & 5 & -0.50 & 6.309 & 0.559 & 0.020 \\
\hline $12 / 20 / 2016$ & 6 & -0.48 & 5.801 & 0.270 & 0.123 \\
\hline $12 / 31 / 2016$ & 7 & -0.20 & 5.111 & 0.040 & 0.577 \\
\hline $01 / 11 / 2017$ & 8 & -0.25 & 5.413 & 0.120 & 0.360 \\
\hline $01 / 22 / 2017$ & 9 & -0.25 & 5.214 & 0.175 & 0.262 \\
\hline $02 / 02 / 2017$ & 10 & -0.22 & 5.067 & 0.361 & 0.115 \\
\hline $02 / 13 / 2017$ & 11 & -0.19 & 4.577 & 0.102 & 0.400 \\
\hline $02 / 24 / 2017$ & 12 & -0.51 & 5.731 & 0.400 & 0.090 \\
\hline
\end{tabular}

560 
Table 2 : Diatom taxa, and biological and environmental parameters

\begin{tabular}{|c|c|c|c|c|c|c|c|}
\hline Diatoms & $\%^{a}$ & Morphology ${ }^{b}$ & Spores & $\begin{array}{l}\mu^{c} \\
d^{-1}\end{array}$ & $T \max ^{d}$ & $\begin{array}{c}\mathrm{Si}\left(\mathrm{OH}_{4}\right)^{\mathrm{e}} \\
\mu \mathrm{M}\end{array}$ & $\begin{array}{c}\mathrm{NO}_{3}{ }^{\mathrm{e}} \\
\mu \mathrm{M}\end{array}$ \\
\hline Proboscia inermis & 100 & $\mathrm{CR}$ & $\mathrm{N}$ & & 7 & 3.18 & 22.1 \\
\hline Membraneis challengeri & 84.3 & PRap & $\mathrm{N}$ & & 10 & 2.45 & 22.8 \\
\hline Thalassiosira antarctica & 78.7 & CR & $\mathrm{Y}$ & 0.17 & 2 & 17.9 & 25.4 \\
\hline Thalassiothrix antarctica & 77.2 & PArap & $\mathrm{N}$ & & 7 & 3.18 & 22.1 \\
\hline Rhizosolenia chunii & 76.6 & $\mathrm{CR}$ & $\mathrm{N}$ & & 7 & 3.18 & 22.1 \\
\hline Pseudo-nitzschia spp. & 68.1 & PRap & $\mathrm{N}$ & 0.067 & 7 & 3.18 & 22.1 \\
\hline Eucampia antarctica & 67.1 & CMP & $Y$ & 0.072 & 7 & 3.18 & 22.1 \\
\hline Corethron inerme & 65.3 & $\mathrm{CR}$ & $\mathrm{N}$ & 0.046 & 7 & 3.18 & 22.1 \\
\hline Odontella weisflogii & 63.4 & CMP & Y & & 7 & 3.18 & 22.1 \\
\hline Chaetoceros (Hyalochaete) & 59.6 & CMP & $\mathrm{Y}$ & 0.13 & 2 & 17.9 & 25.4 \\
\hline Navicula directa & 58.4 & PRap & $\mathrm{N}$ & & 8 & 4.52 & 21.9 \\
\hline Fragilariopsis kerguelensis & 49.6 & PRap & $\mathrm{N}$ & 0.077 & 2 & 17.9 & 22.8 \\
\hline Thalassionema nitzschioides & 44.2 & PRap & $\mathrm{N}$ & 0.11 & 2 & 17.9 & 22.8 \\
\hline
\end{tabular}

563

$564{ }^{a}$ percentage of the seasonal export achieved during the periods denoted with stars in Figure 5653

$566{ }^{\mathrm{b}} \mathrm{CR}$ centric radial, PRap Pennate raphid, CMP centric multipolar

$567{ }^{c}$ net growth rate determined from the increase in cell abundance during the growing phase

568 of the population.

569 Spores: indicates whether diatom species produces spores $(\mathrm{Y})$ or not $(\mathrm{N})$

$570 \mathrm{~d}$ sample number when the abundance was maximum.

571 e Concentrations in $\mu \mathrm{mol} \mathrm{L^{-1 }}$

572

573

574 


\section{List of figure legends:}

Figure 1: Chlorophyll seasonal changes and location of the mooring site. (A) Global view of the mooring site on the central Kerguelen plateau. The white dot denotes the position of the RAS mooring overlaying monthly chlorophyll for November 2016. The white rectangle denotes the zone that is detailed in the SI Figure 1. (B) The green line presents the climatology (1998-2017) at the mooring site with standard deviation represented with the light green shaded area. The blue line represents the chlorophyll concentrations from 8-days color satellite images at the same site for the period extending from Oct 2016 to April 2017. The vertical dotted line denotes the sampling dates.

Figure 2: Seasonal changes in the Kerguelen bloom. (A) The synchronized sampling strategy was based on an autonomous sampler collecting water in the mixed layer at $42 \mathrm{~m}$ and a sediment trap deployed at 300 m collecting the sinking flux. The stars denote dates when phytoplankton samples were collected. The white rectangles along the $\mathrm{x}$ axis, numbered 1 to 12 , are the periods of collection in the sediment trap cup. (B) Relative contribution of the different diatoms to the total diatom carbon biomass $\left(\mathrm{POC}_{\text {diat }}\right.$ ) at $42 \mathrm{~m}$. Diatoms are ordered according to their carbon content (SI 5 Data). Abbreviations for genus names are Asteromphalus (A.), Corethron (C.), Chaetoceros (Ch.), Eucampia (E.), Fragilariopsis (F.), Guinardia (G.), Membraneis (M.), Navicula (N.), Odontella (O.), Proboscia (P.), Pseudonitzschia (P.*), Rhizosolenia (R.), Thalassiothrix $\left(T .{ }^{*}\right)$, Thalassiosira (T.), Thalassionema (T.\#). (C) integrated $\mathrm{POC}_{\text {diat }}$ in the mixed layer (black bars). The white circles denote the surface chlorophyll concentrations derived from 8 day composite images. (D) Silicic acid (white circle) and nitrate (grey square) concentrations measured in the filtered samples collected with RAS at $42 \mathrm{~m}$. 
Figure 3: Seasonal changes of diatom abundance in relation to carbon biomass.
(A) Community Weighted Mean
(B) total abundance (C)
(C) total carbon biomass. For all the plots the dots denote the value estimated from observation and the boxplot (median, first and third quartile) visualize the variability of the estimates based on 1000 simulations of diatom community assuming a normal distribution of the traits around the observed value with a variation coefficient of 0.5. (D) Diatom abundance $\left(\mathrm{N}_{\mathrm{t}}\right)$ versus CWM for 1000 communities resulting from random composition and abundance of the different species according to observations (see methods for details). The black line represent the fitting of the equation $\mathrm{N}_{\mathrm{t}}=\mathrm{POC}_{\text {diat }} / \mathrm{CWM}$ with $\mathrm{POC}_{\text {diat }}=0.097 \mathrm{mg} \mathrm{L}^{-1}$.

Figure 4 : Carbon export fluxes by diatoms. A) Total diatom carbon flux in each cup B) relative contribution of different taxa to total diatom carbon flux in each cup. Abbreviations for genus names are Asteromphalus (A.), Corethron (C.), Eucampia (E.), Fragilariopsis (F.), Membraneis (M.), Navicula (N.), Odontella (O.), Proboscia (P.), Pseudo-nitzschia $\left(P .{ }^{*}\right)$, Rhizosolenia (R.), Thalassiothrix $\left(T .^{*}\right)$, Thalassiosira (T.), Thalassionema (T.\#).

Figure 5 : Temporal changes in the relative contribution to the cumulated seasonal abundance of a given taxon (upper panels), and to the carbon export flux of the same taxon (lower panels). Vegetative cells are shown in black and spores are presented in gray. For clarity, only 1 tick every 2 cups is presented and only cup numbers 2, 6 and 10 are labeled.

Figure 6 : Comparison of the maximum seasonal abundances of the different diatom taxa (white circles), with the critical abundance derived from the aggregation model of Jackson. The shaded areas represent all the possible critical abundances considering different combinations of $\mu$ and $\alpha$ as indicated on the right $y$-axis. 
624 We thank the captains and the crew of the R/V Marion Dufresne for their support during the 625 cruises. We thank E. de Saint Léger, F. Pérault and L. Scoarnec from DT-INSU, and people of 626 IPEV (Institut Polaire Paul Emile Victor) for the technical support during preparation, 627 deployment and recovery of moorings. We also thanks Tom Trull who inspired the use of 628 RAS for our project and Diana Davis for her valuable advises in the preparation of this 629 equipment. We thanks the associate editor S. Menden-Deuer and the 4 anonymous 630 reviewers for their constructive comments. This work is part of the project SOCLIM 631 supported by the Climate Initiative of the foundation BNP Paribas, the French research 632 program LEFE-CYBER of INSU-CNRS, IPEV, Sorbonne Université, and the Flotte 633 Océanographique Française. The authors declare no conflict of interest. 
(A)

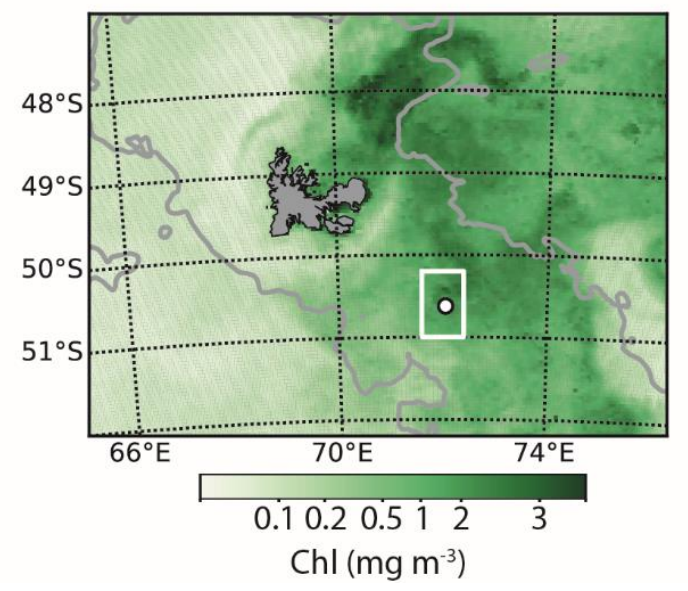

(B)

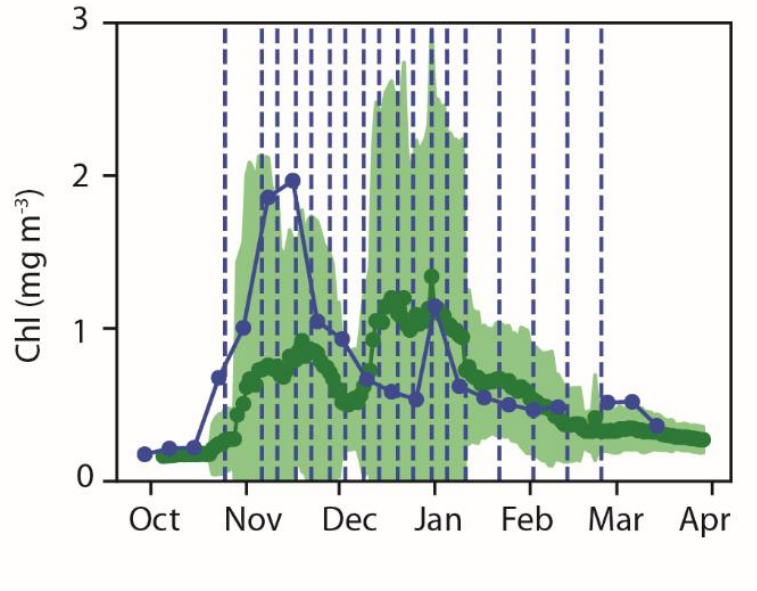

Figure 1 
(A)

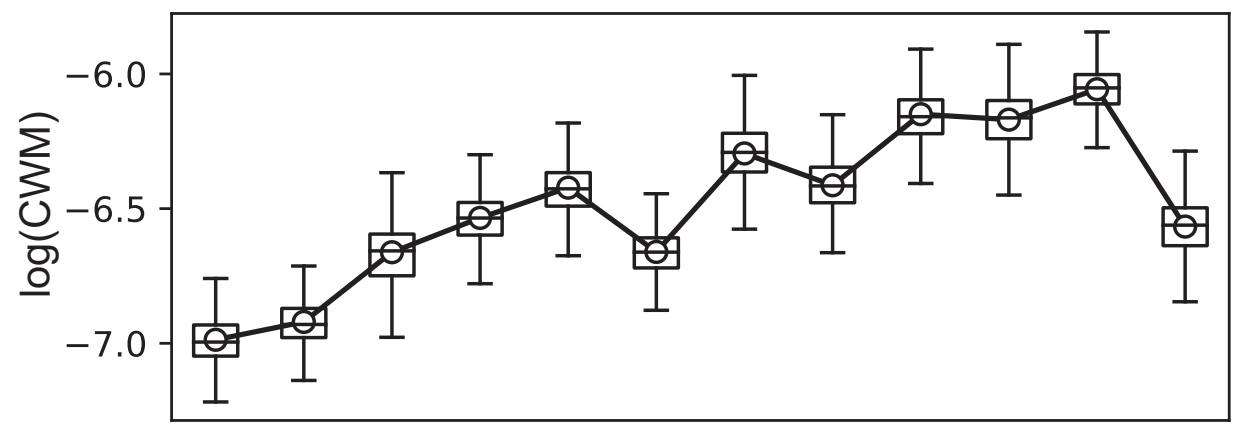

(B)

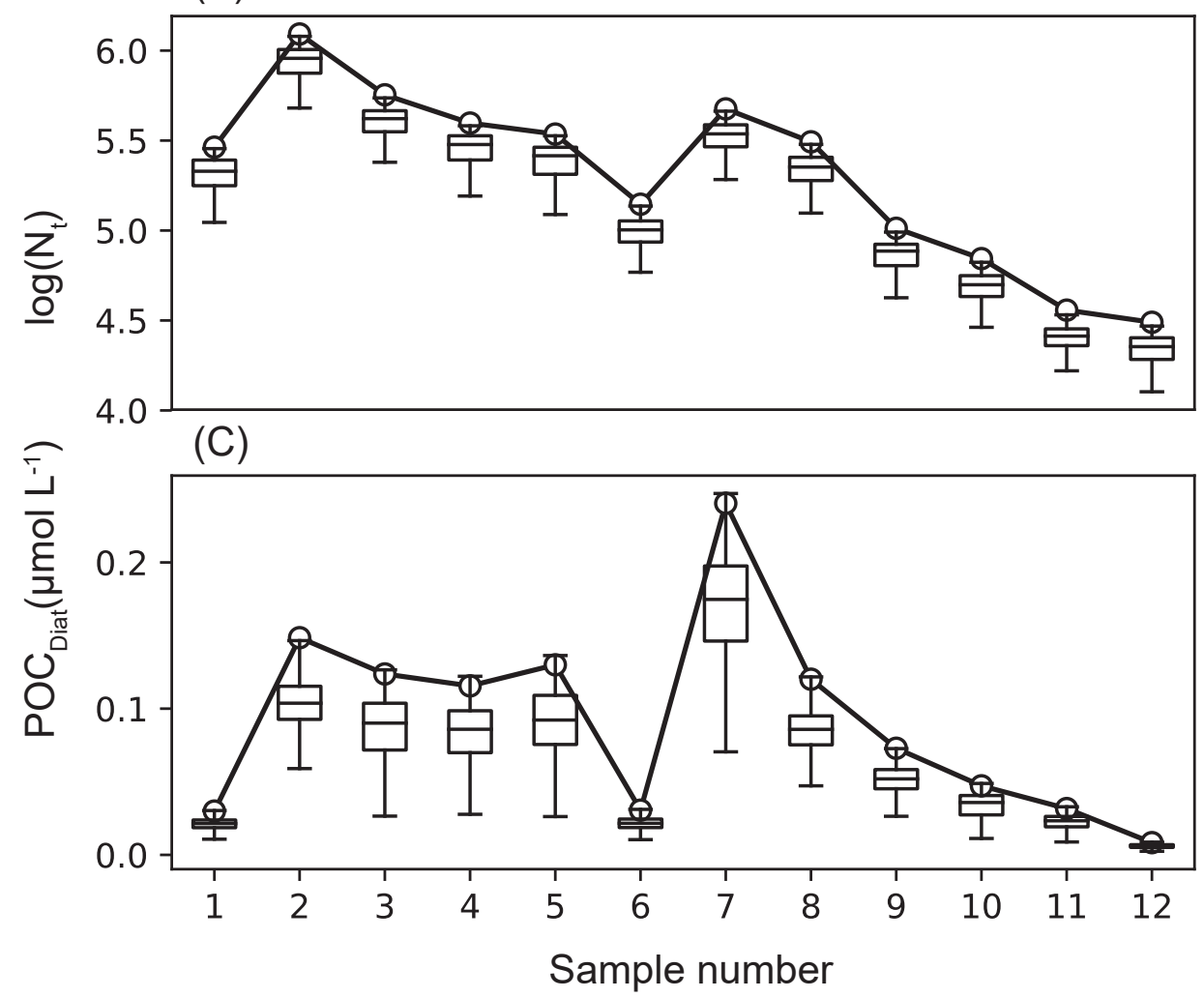

(D)

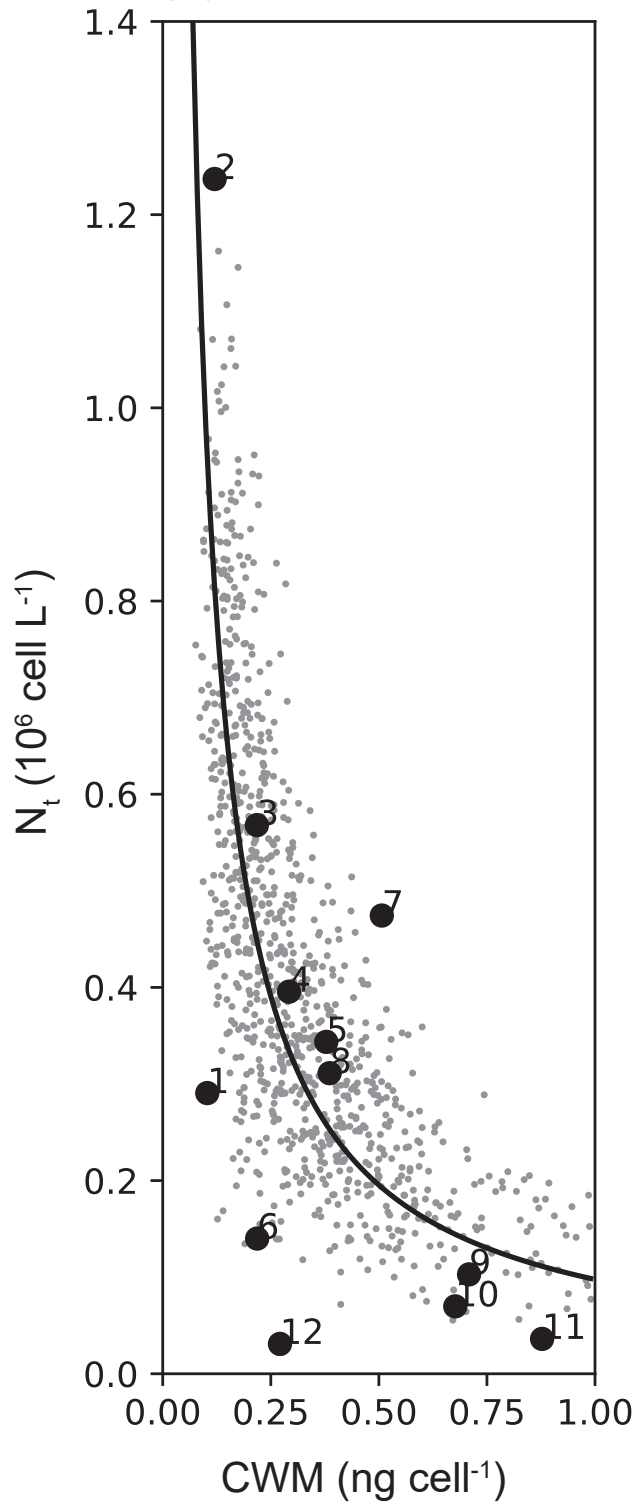

Figure 3 


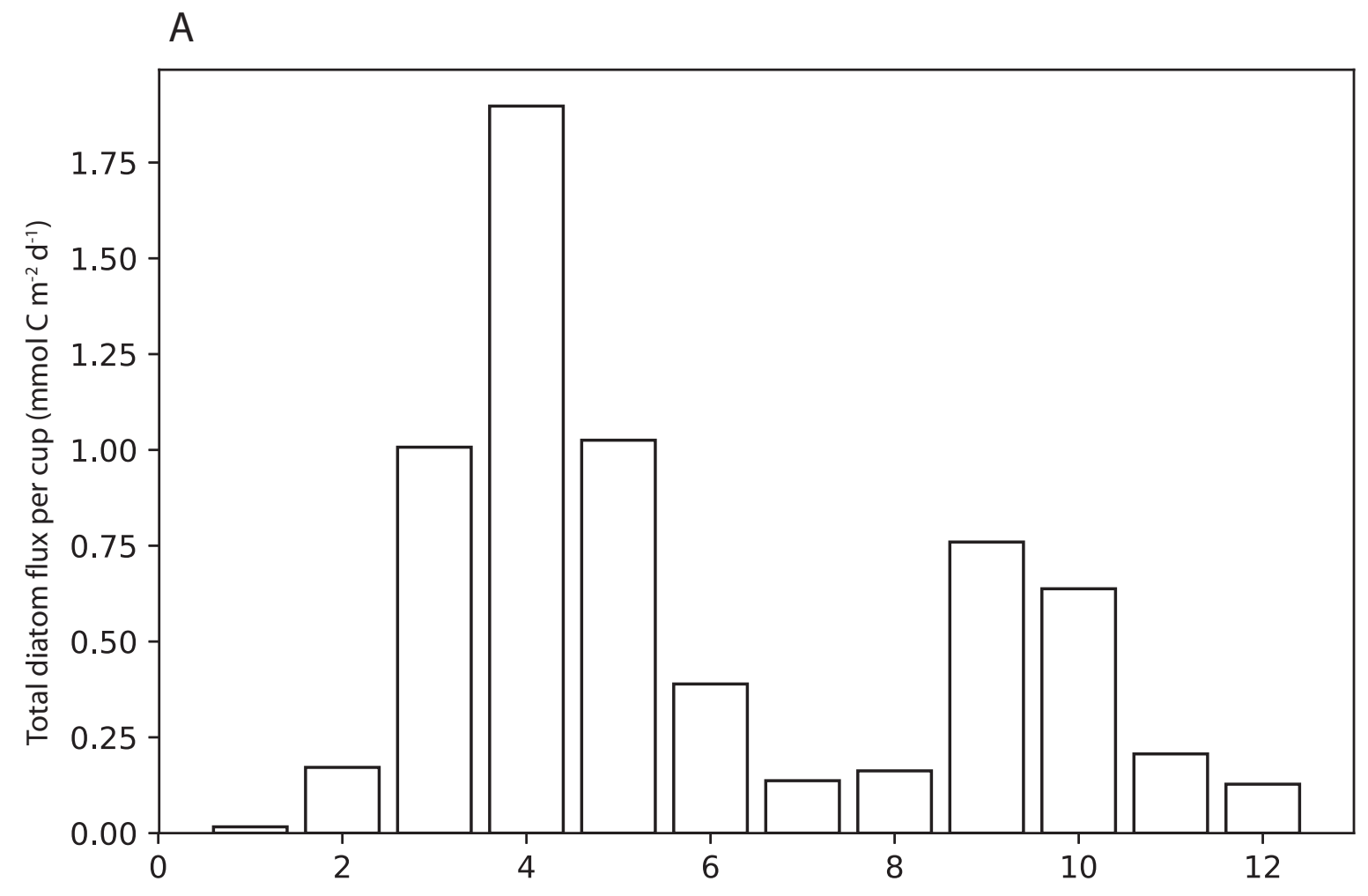

B

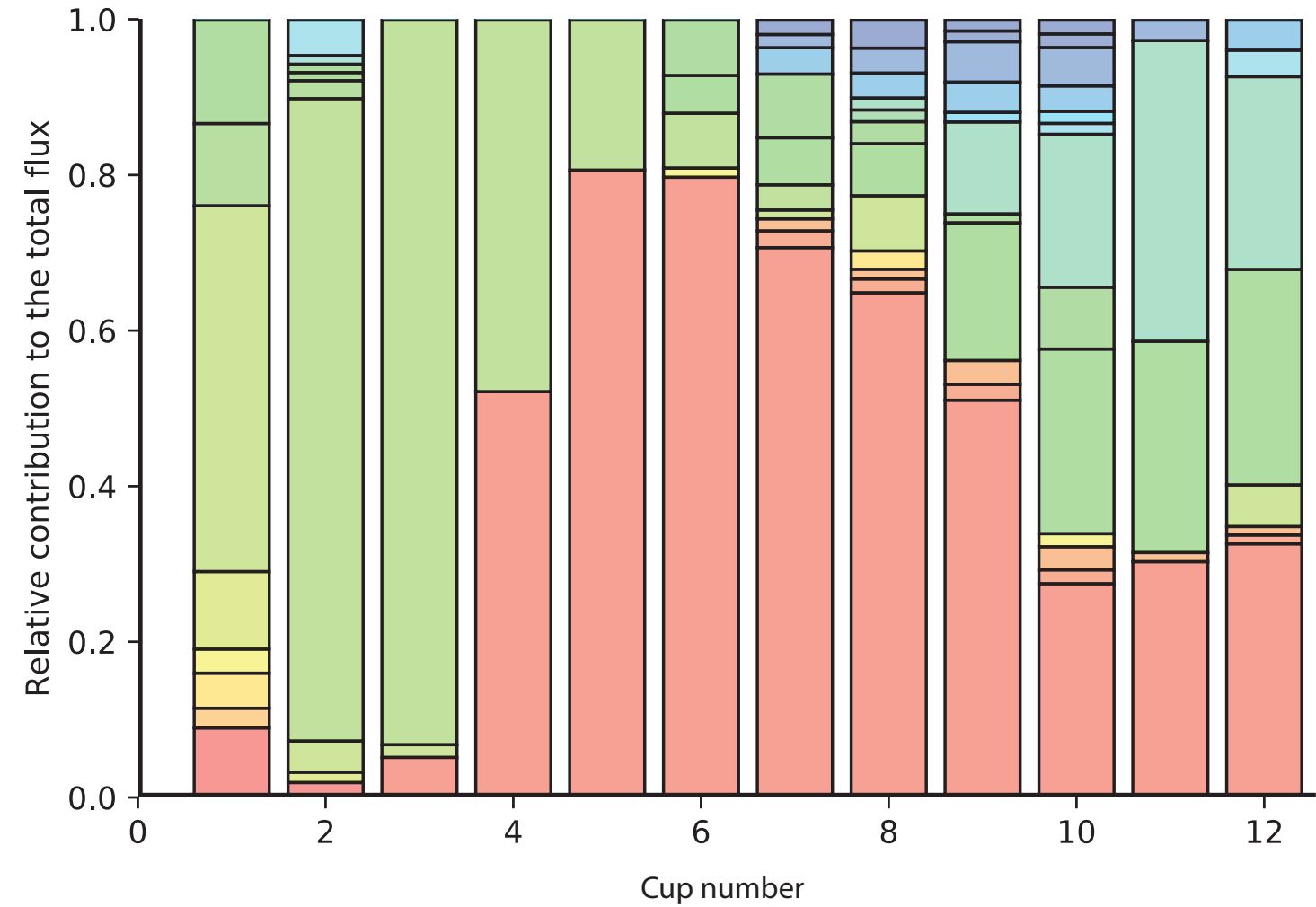

$\square$ A. hookeri

$\square$ R. styliformis

$\square$ M.challengeri

$\square$ T.* antarctica

$\square$ P.inermis

$\square$ T.lentiginosa

$\square$ O. weisflogii

$\square$ O.weisflogii spores

$\square$ R.antennata

$\square$ C. inerme

E.antarctica

$\square$ R.chunii

$\square$ T.antarctica spores

$\square$ T.antarctica

$\square$ T. resting spores

$\square$ F. kerguelensis

$\square$ small centric

$\square$ N.directa

$\square$ F. separanda

$\square$ T.gracilis

$\square$ P.*heimeii

$\square$ P.* lineola

$\square$ C. resting spores

$\square$ T.\# nitzschioides

Cup number

Figure 4 


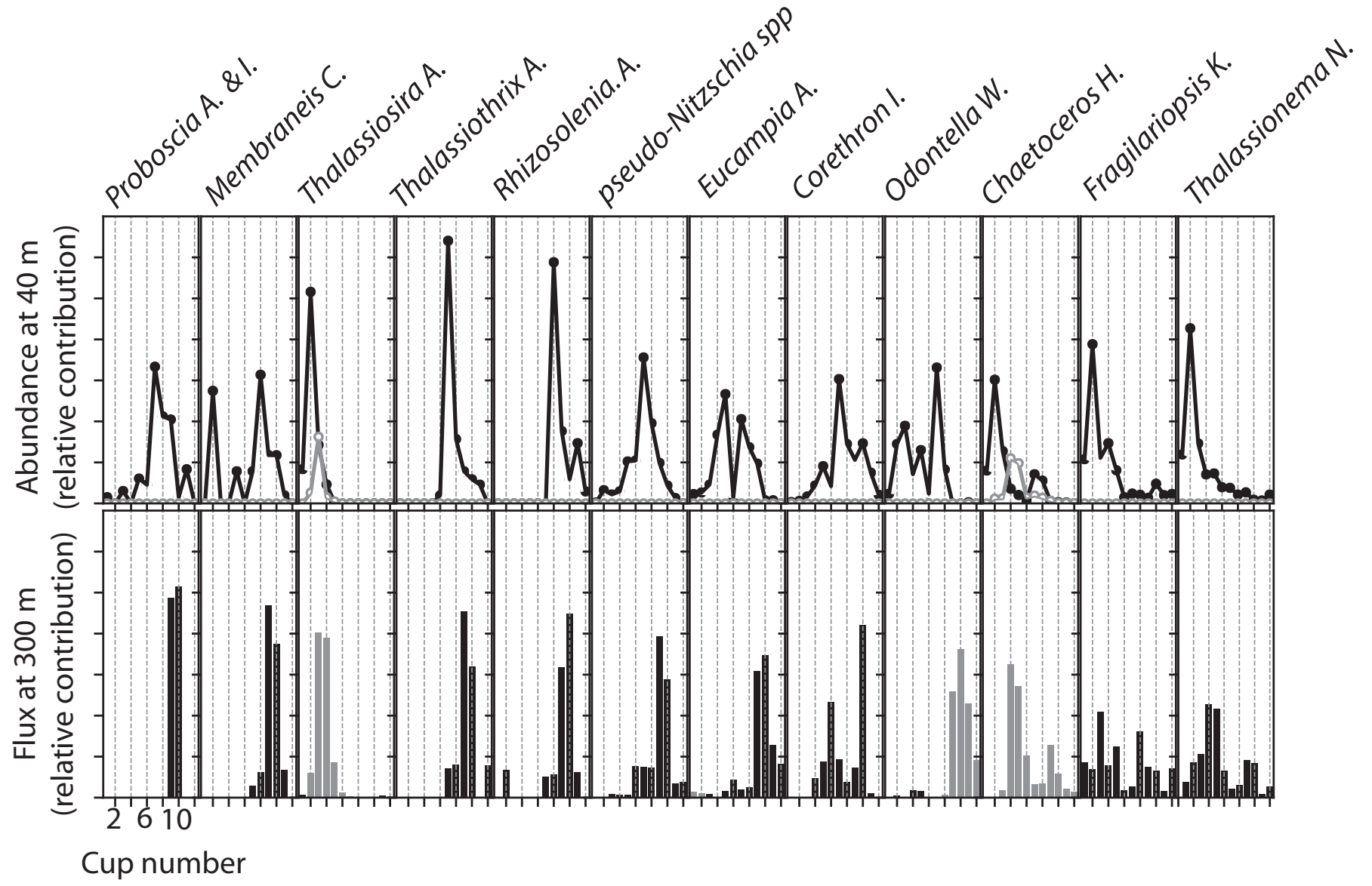

Figure 5 


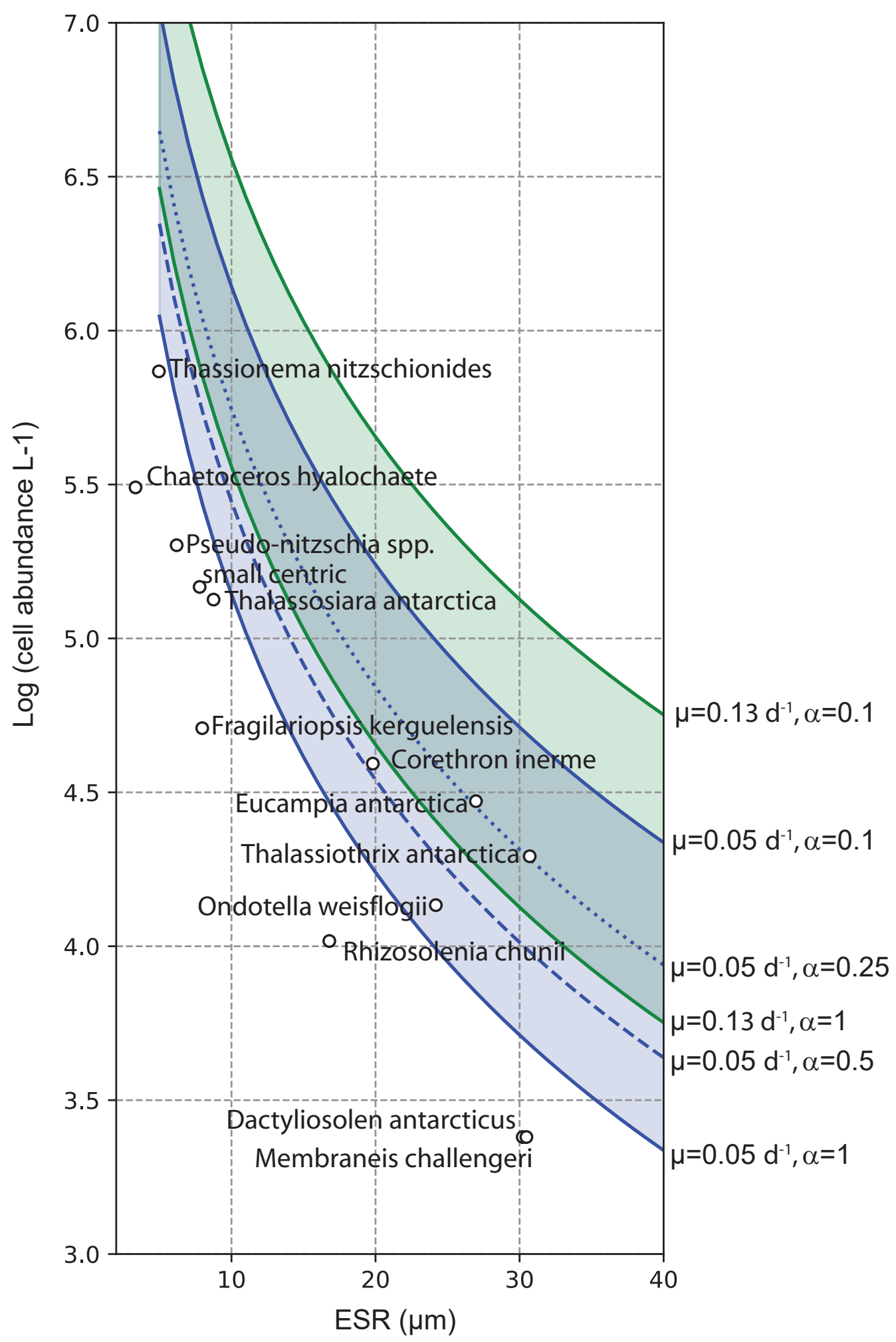

Figure 6 